\title{
By Hook Or By Crook: From Pedicab Drivers To Company Owners Through Start-Up Worker Co-Operatives
}

\author{
Novita Puspasari ${ }^{1 *}$, Yanuar E. Restianto ${ }^{1}$ \\ ${ }^{1}$ Jurusan Akuntansi, Fakultas Ekonomi dan Bisnis, Universitas Jenderal Soedirman \\ *Email corresponding author: novita.puspasari@unsoed.ac.id \\ Diterima 04/03/2020 Direvisi 11/03/2020 Diterbitkan 31/01/2020
}

\begin{abstract}
Disruption of information technology has threatened several jobs in the informal sector. As a result, the income gap between the rich and the poor can get wider. In Purwokerto, Central Java, the emergence of online application-based transportation has disrupted the work of becak drivers. This research used action research method. In action research, researcher conduct research and at the same time make changes and interventions to the object. In the first stage, diagnosis, it was found that becak drivers' work was no longer competitive. Therefore, the intervention made with establishing a start-up worker co-operatives model, an online-based worker-cooperative for former becak drivers. In this model, becak drivers are directed to work in service sectors, such as cleaning service, gardener, plumber, and other service works. Ordering process can be made through online application which can be downloaded for free in android devices. There are two implications in this study. First, in theory, this study offers a relatively new model, start-up worker co-operative. This model enables all workers to be owners in their co-operative company. Second, in practice, if successfully implemented, this model can be replicated for other sectors and other regions. As a result, start-up worker co-operative can be one solution to overcome income inequality. Keywords: Start-up, Worker co-operative, Action research, Becak drivers, Disruption.
\end{abstract}




\section{INTRODUCTION}

Technology has disrupted various aspects of life, including business. Many established incumbent industries have fallen when they have to deal with "new players" in the business world. These "new players" are usually small businesses like start-ups which rely on technology on its dayto-day business. The technology carried by startups could be significantly cheaper and still provide the desired features. Because of its small size, these start-ups can be more agile in facing the dynamic business world. They respond more quickly to consumer desires and innovate faster.

Indonesia is in the top five countries in the world with the highest number of startups (TechinAsia, 2018). The total reached 1,705 startups, placing Indonesia fourth behind the United States (28,794 startups), India (4,713 startups), and the United Kingdom (2,971). In the Southeast Asia region, there are currently seven unicorn startups, namely a degree given to a startup that has a valuation value of more than US $\$ 1$ billion. Out of these seven, Indonesia contributed four startups; Go-Jek, Tokopedia, Traveloka, and Bukalapak. The other three are Sea Ltd and Grab from Singapore, and Revolution Precrafted from the Philippines.

On the other side, technology has also disrupted several jobs in the informal sector. In Purwokerto, Central Java, the emergence of online application-based transportation such as Gojek and Grab has disrupted the work of traditional becak drivers. However, in other country like Pakistan, start-ups have been "the hero" of their informal labour, since their start-ups have been successful in changing existing business model which placed informal workers in unfavourable situation such as low wages and no health insurance.

This paper aims to identify becak driver's problems due to disruption of online transportation, explore the possibility of creating an alternative source of income for becak drivers as well as develop the model of that alternative source of income. The novelty of this study is in bridging previous studies on startup and worker cooperative. Some previous research in digital startup (Ries, 2011., Groenewegen, G and F. de Langen, 2012., Destyana and Riyanti, 2017., and Ghezzi, 2018) emphasized more in conventional model of startup as a company, while other research in worker cooperative (Perotin, 2012., Artz and Kim, 2011) focused merely on worker cooperative model. This research attempt to bridge the two areas and implement the findings in order to make a change in the object.

\section{TINJAUAN PUSTAKA DAN PERUMUSAN HIPOTESIS}

\section{Disruptive Innovation}

The term "disruptive innovation" first coined by Clayton Christensen in 1995. Disruptive innovation refers to a process when product or service from newly emerged companies take over the established competitors or incumbents. The disruptors are often small companies while the incumbents are big and well-established companies. Based on Christensen (2015), there are some characteristics of disruptive companies: gross margins are lower, target markets are smaller, products and services are simpler and as a solution of the existing problem in the market. Digital start-up is often associated as a disruptive innovation model.

Website

\section{Start-up and Lean Start-up}

The vision of start-up according to Ries (2011) is to create profitable businesses that can change the world. The goal of start-up is to find out exactly what should be made of goods and/or services that consumers want thus make them want to pay in the shortest possible time. Meanwhile, lean start-up is a new way to develop innovative new products with pressure on rapid trial and error, consumer interest, big vision, and exorbitant ambitions. The five principles in Lean Start-Up according to Ries (2011) are: entrepreneurs are everywhere (entrepreneurs can be found 


\section{PERFORMANCE}

Jurnal Personalia, Financial, Operasional,

Marketing dau Sistem Informasi

Performance. Volume 27 Nomor 1 Tahun 2020, 41-50

anywhere and the Lean Startup approach can be applied in companies as big or small, in any sector or industry), management is the key to entrepreneurship (Startup should be seen as an institution, not just a product, therefore it requires a new type of management specifically designed to deal with extreme uncertainty), validated learning (the biggest problem with conventional start-ups is business sustainability. Thousands of start-ups appear every year and thousands also stop operating. This learning can be scientifically validated by routine experiments that allow entrepreneurs to test every element of their vision), Build-Measure-Learn (the startup's fundamental activity is to transform ideas into products, measure consumer responses, and then assess whether they should stop or survive), innovation accounting (to assess the success of a startup, a new type of measuremen is needed. This is called accounting innovation).

\section{Critical Success Factors of Start-Up}

Based on Groenewegen and De Langen (2012) there are two groups contributing to critical success factors (CSF) which are organizational and entrepreneurial. This also support research from De Mel et al. (2009) which found that innovation in company depends on the owner. On the level of organization, success will be determined by comprehensive business plan, clear strategy and competitor analyses and aggressive competitor strategy (Brem, 2008; Rauch, 2000). The use of innovation as a business idea, member of a formal network and advisory board and active marketing also contributing to comprehensive business plan (Nandram\&Boemans, 2001; Rauch, 2000). Aside from organizational level, entrepreneurial level consists of: the need for achievement, having locus of control, willingness to take risks, experience as entrepreneur, industry specific experience, management experience and social network which is relevant (Brem, 2008; Nandram\&Boemans, 2001; Rauch, 2000).

\section{Worker Cooperative}

Worker cooperative is a form of cooperative whose its enterprise managed and controlled democratically by their workers. Worker cooperative in Indonesia often mislead to employee cooperative although they are different. This worker cooperative applies cooperative values and are driven to put benefits for workers and the community as the ultimate goal. In contrast to traditional companies, members of workers in worker cooperatives participate in creating profits and managing enterprise in a democratic manner. This model proves to be an effective tool for creating and maintaining sustainability, more dignified work, improving the quality of life of workers and promoting community development and local economics, especially for people who have difficulty accessing business ownership and sustainable employment choices.

There are many definitions of worker's cooperative. In fact, the definition may be different in some countries. However, CICOPA, the Organization of Industrial and Service Coperative, provides widely-used definition in the World Declaration on Workers Cooperatives. The following is a section on the basic characteristics of workers' cooperatives: 1) It has a goal of creating and sustaining jobs that are sustainable and generate wealth, to improve the quality of life of workers, glorify human work, enable the independent management of workers in a democratic manner and promote community and local development. 2) Free and voluntary membership - in order to contribute to the workforce and personal economy - is conditioned by the existence of the workplace. 3) As a general rule, work must be carried out by members. This implies that the majority of workers in a cooperative enterprise are members and vice versa. 4) Workers-member relations with their cooperatives must be considered different from conventional wage-based employment relationships and from individual independent work relations. 5) Internal regulations are formally determined by regimes that are democratically approved and accepted by workermembers. 6) They must be independent and independent before the state and third parties, in 
relations and work management, as well as in the use and management of the means of production.

\section{RESEARCH METHODOLOGY}

Davison, Martinsons and Kock (2004) stated that knowledge is always gained through series of action and for action. To question the validity of social knowledge is to question, not how to develop a reflective science about action, but how to conduct an action science. This research used action research. Action research is problem centered and action-oriented research. This research used action research method. Action research is a method which enables researcher to describes, interpret, and explain a social situation and at the same time at the same time creating changes or interventions with the goal of improving community through series of participation (Sulaksana, 2004). Davison, Martinsons and Kock (2004) mentioned that action research as a method of research, action research founded on the assumption that the theory and practice can be integrated with the learning of the outcome of the interventions planned after a detailed diagnosis of the context of the problem.

The stages of this study are based on the stages of action research stated by Davison, Martinsons and Kock (2004). According to Davison, Martinsons and Kock (2004), there are five stages in action research: diagnosis, action planning, action-taking, evaluating and learning. This action research will take approximately three years to be completed. In diagnosis phase, we try to identify the problems faced by becak drivers and explore the possibility to create new opportunity for them. In the action planning phase, we try to develop the lean start-up model as well as worker co-operative model. In action taking phase, we operasionalize the model and try to develop it more. In the evaluation phase, we try to analyze impacts and benefits of the model. Data collection used in this study will be dominated by in depth interview and Focus Group Discussion (FGD). Based on the reference stage of the action research, the stages in this study and the methods and outcomes described in the following chart:

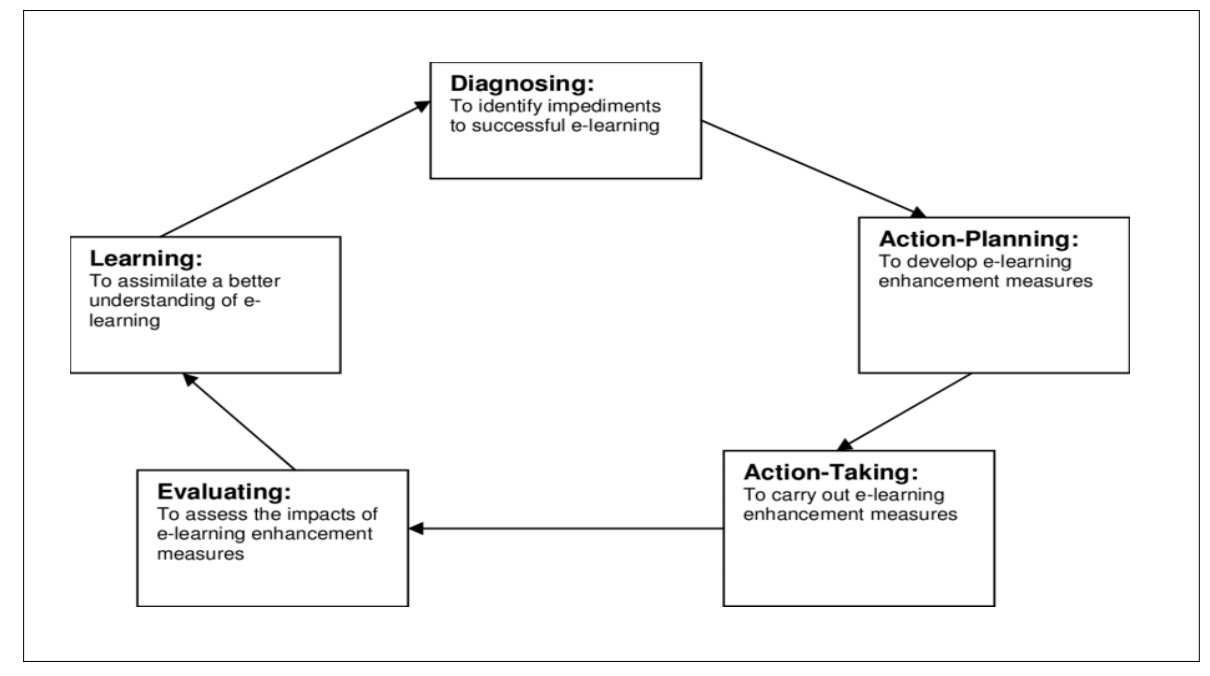

Picture 1. Phases of Action Research

Source: Lee-Post (2009) 
PERFORMANCE

Jurnal Personalia, rinancial, Operasional,

Performance. Volume 27 Nomor 1 Tahun 2020, 41-50

Table 1. Action Research Phase

\begin{tabular}{|c|c|c|c|c|c|}
\hline Action Research Phase & $\begin{array}{l}\text { Diagnosis } \\
\text { (1) }\end{array}$ & $\begin{array}{c}\text { Action Planning } \\
\text { (2) }\end{array}$ & $\begin{array}{c}\text { Action Taking } \\
\text { (3) }\end{array}$ & $\begin{array}{l}\text { Evaluation } \\
\text { (4) }\end{array}$ & $\begin{array}{l}\text { Learning } \\
\text { (5) }\end{array}$ \\
\hline Research Phase & $\begin{array}{l}\text { - Identify becak } \\
\text { driver's problems } \\
\text { due to disruption of } \\
\text { online } \\
\text { transportation. } \\
\text { - Explore the possibility } \\
\text { of creating an } \\
\text { alternative source } \\
\text { income for becak } \\
\text { drivers (type of goods } \\
\text { and services needed } \\
\text { by potential } \\
\text { consumer) and } \\
\text { platform (offline and } \\
\text { online) }\end{array}$ & $\begin{array}{l}\text { Develop a model } \\
\text { of alternative } \\
\text { source of income } \\
\text { for becak drivers } \\
\text { under worker } \\
\text { cooperative } \\
\text { scheme } \\
\text { Develop start-up } \\
\text { platform as a tool } \\
\text { of becak driver's } \\
\text { worker } \\
\text { cooperative and } \\
\text { to increase local } \\
\text { competitiveness. }\end{array}$ & $\begin{array}{l}\text { - } \\
\text { beveloping android } \\
\text { based application } \\
\text { Recruting becak } \\
\text { drivers } \\
\text { - Pilot test on the } \\
\text { market } \\
\text { - Implement the } \\
\text { start-up worker } \\
\text { cooperative model }\end{array}$ & $\begin{array}{l}\text { - Analyze impacts } \\
\text { and benefits of the } \\
\text { model }\end{array}$ & $\begin{array}{l}\text { - Improve and } \\
\text { develop start-up } \\
\text { worker } \\
\text { cooperative } \\
\text { model }\end{array}$ \\
\hline Methods Used & $\begin{array}{l}\text { Data mining (becak } \\
\text { drivers) through in- } \\
\text { depth interview. }\end{array}$ & $\begin{array}{l}\text { - Focus Group } \\
\text { Discussion }\end{array}$ & & $\begin{array}{l}\text { - In- Depth Interview } \\
\text { - Questionnaire }\end{array}$ & $\begin{array}{ll}\text { - } & \text { In Depth } \\
& \text { Interview } \\
\text { - } & \text { Focus Group } \\
& \text { Discussion } \\
\end{array}$ \\
\hline Finding/Output & $\begin{array}{l}\text { - } \quad \text { Becak drivers need } \\
\text { is irrelevant compa } \\
\text { - Service based jobs } \\
\text { (gardening, cleanin } \\
\text { chosen due to prev } \\
\text { - The requirement to } \\
\text { people) is a barrier }\end{array}$ & $\begin{array}{l}\text { to find other service-ba } \\
\text { red to online transporta } \\
\text { chosen for becak driver } \\
\text { g house, painting, etc). } \\
\text { ious identification on c } \\
\text { establish worker co-op } \\
\text { for worker co-operative }\end{array}$ & $\begin{array}{l}\text { d jobs since driving becak } \\
\text { on. } \\
\text { a household jobs } \\
\text { usehold services are } \\
\text { tomer's need. } \\
\text { ative in the Act (min. } 20 \\
\text { nodel }\end{array}$ & \multicolumn{2}{|c|}{$\begin{array}{l}\text { - Assessment (benefit analysis) and } \\
\text { development (business diversification } \\
\text { plan). }\end{array}$} \\
\hline
\end{tabular}




\section{PERFORMANCE}

Jurnal Personalia, Financial, Operasional,

Marketing dam Sistem Informasi

Performance. Volume 27 Nomor 1 Tahun 2020, 41-50

\section{RESULTS AND DISCUSSION}

\section{First Year: Diagnosis and Action Planning}

In the first year, we conducted series of in-depth interviews and informal meetings with becak drivers. We gathered a community namely "Perjaka" (Persatuan Tukang Becak Jalan Kampus). Perjaka has long been a community which is assisted by Kopkun (Koperasi Kampus Unsoed). We tried to dig information about problems they faced in competing with other type of transportation, such as online-based transportation. They said that in the past 7-8 years, their income has been reduced significantly. Their income has been reduced significantly because of two things: first, people tend to buy their own vehicle so that they can be more flexible in commuting and second, the emergence of online-based transportation such as Gojek and Grab in Purwokerto. On average, in one day, becak driver only get 1 customer. Furthermore, many of them sometimes did not get any customer in one to three days. They still rely their living in driving becak because they perceive that they do not have any other skills thus they cannot find other prominent jobs. Demographically, they are not educated and old in age (beyond fourty five).

We conducted observations as well as in depth interviews to explore the possibility of creating an alternative source income for becak drivers. We found out that becak drivers actually have other skills such as: gardening, plumbing and home/office cleaning. Thus, we initiated a start-up platform named PediHelp as a platform which provides home/office cleaning, gardening, and plumbing service. Start-up platform was chosen since it provides more effective, efficient and modern way in conducting business.

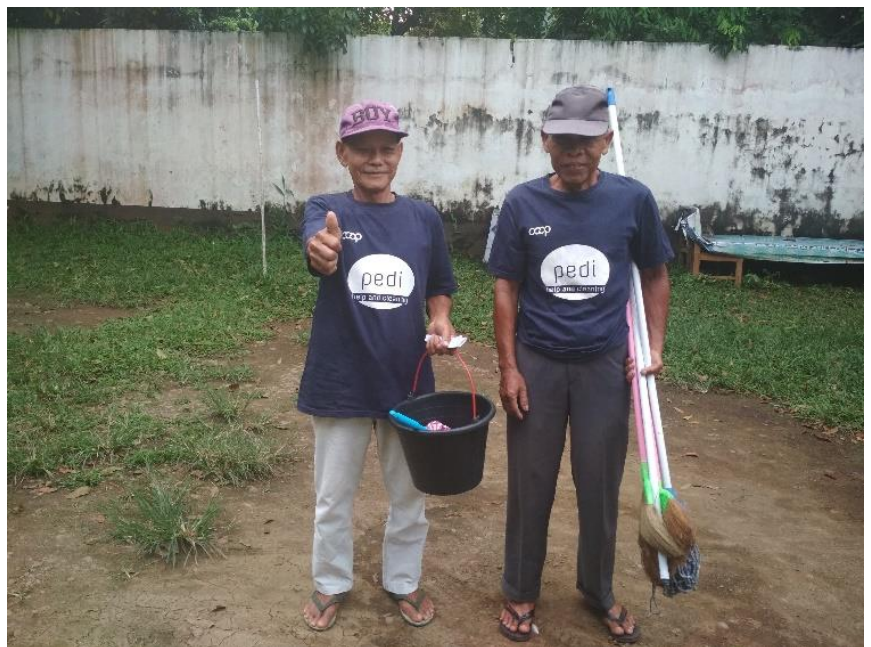

Figure 2. Becak Drivers under PediHelp start-up worker co-operative

PediHelp was initiated in September 2017 in Purwokerto. Starting from a group of pedicab drivers who had difficulty earning a living, we initiated cleaning services for pedicab drivers to earn extra income. PediHelp's big vision is to employ informal workers to be more competitive and professional. Currently PediHelp is incubated by Kopkun Institute (kopkuninstitute.org) and is part of the Kopkun Coop Incorporated (kopkun.com), a cooperative group that houses several other newly formed cooperatives.

PediHelp choose "worker cooperative" as a business model. In worker cooperative, the workers (becak drivers) not only work as employee of cooperative, but also as owner of cooperative. In 


\section{PERFORMANCE \\ Jurnal Personalia, Financial, Operasional, Marketing dam Sistem Informasi}

Performance. Volume 27 Nomor 1 Tahun 2020, 41-50

contrast to traditional start-up companies, members of workers in start-up worker cooperatives participate in creating profits, corporate management in a democratic manner. Thus, the becak drivers will not noly become "the object", but also become "the subject" in economy.

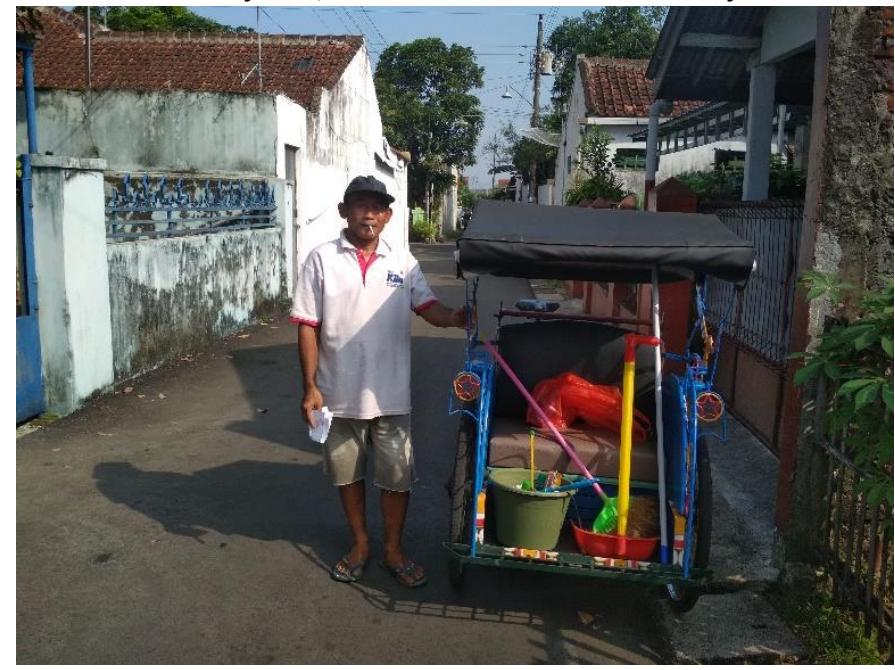

Figure 3. Becak Drivers converting to Home Cleaner

\section{Second Year: Action Taking}

Some previous research in digital startup (Ries, 2011., Groenewegen, G and F. de Langen, 2012., Destyana and Riyanti, 2017., and Ghezzi, 2018) found that the first three years of digital startup were the critical ones in spite of misbalancing management and business. PediHelp went through the second year also by tried to balance between those two.

After diagnosis phase, we develop a model of alternative source of income for becak drivers under worker cooperative scheme and also we develop start-up platform as a tool of becak driver's worker cooperative and to increase local competitiveness. Furthermore, we develop android based application which is available in Google Play Store. PediHelp is now available in website (PediHelp.id) and in Google Play Store (Pedi Solution Application). We did not have enough money to fund the development of online based application. Consequently, we collaborate with other party (program developer company) to develop the application.

We did a market test before we launched the App. The result of our market test was there was a huge demand of such services (cleaning, gardening, plumbing) in Purwokerto area since the cost for having household assistant are now getting bigger. The number of becak drivers joined in startup worker co-operative PediHelp are increased as the demand for their cleaning service has also increased. There are about 18 becak drivers who own this co-operative start-up company recently. 


\section{pedi help $\mathcal{E}$ cleaning}

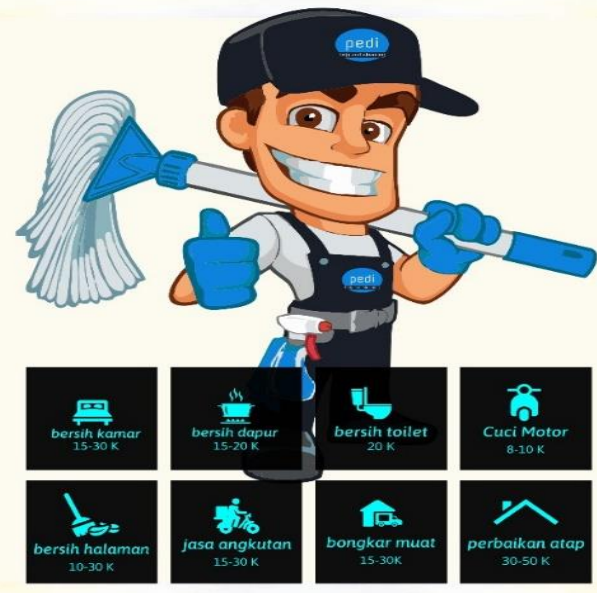

Pedi help \& cleaning melayani jasa bantuan dan kebersihan untuk

wilayah kampus Unsoed dan sekitarnya. Selain produk di atas kami juga bersedia melayani bantuan apa saja yang memungkinkan di lakukan dengan tenaga. daerah layaran

pabuaranl grendeng| sumampirl bancarkembar

(마) permesaran
085651925228 pedi help\&́cleaning
08565

Figure 4. Pedi flyer to market its services

\section{CONCLUSION}

Technology has disrupted several jobs in the informal sector, however at the same time, it creates another job opportunity. In Purwokerto, Central Java, the emergence of online applicationbased transportation has disrupted the work of becak drivers. This research used action research method. In action research, researcher describes, interprets, and explains a social situation at the same time by making changes or interventions for the purpose of improvement or participation. There are five steps in action research: diagnosis, action planning, action taking, evaluation and learning.

In the first stage, diagnosis, it was found that becak drivers' work was no longer competitive. Therefore, the intervention made with a start-up worker co-operatives model, an online-based worker-cooperative for former becak drivers. In this model, becak drivers are directed to work in service sectors, such as cleaning service, gardener, plumber, and other service works. Ordering process can be made through online application which can be downloaded for free in android devices. In action planning phase, we develop the android-based application namely PediHelp. In action taking, we conducted pilot market test to test the demand for household services. It found out that the demand for those services were high, thus the apps also launched in this phase.

There are two implications in this study. First, in theory, this study offers a relatively new model, start-up worker co-operative. This model enables all workers to be owners in their co-operative company. Second, in practice, if successfully implemented, this model can be replicated for other sectors and other regions. As a result, start-up co-operative worker can be one solution to overcome income inequality. 


\section{REFERENCES}

Artz, G., Kim, Y. (2011). Business Ownership by Workers: Are Worker Cooperatives a Viable Option?. Working Paper No. 11020 November 2011 lowa State University: Department of Economics.

Brem, A. (2008). The Boundaries of Innovation and Entrepreneurship. Wiesbaden: Erlangen Nürnberg.

CICOPA International Organization of Industrial and Service. (2018). Accessed in https://www.cicopa.coop

Chataway, C. (1997). An examination of the constraints on mutual inquiry in a Participatory Action Research project. Transforming Psychology: Interpretive and Participatory Research Methods. Journal of issue, V4. No.53 p747 (19).

Christensen, C. M., Raynor, M. and McDonald, R. (2015). ' What is disruptive innovation?'. Harvard Business Review, 93, 44- 53.

Davison, R. M., Martinsons, M. G., Kock N. (2004). Principles of Canonical Action Research. Information Systems Journal, 14, 65-86.

Dessyana, A., Riyanti, B. (2017). The Influence of Innovation and Entrepreneurial Self-Efficacy to Digital Startup Success. International Research Journal of Business Studies vol. X no. 01

Ghezzi, A. (2018). Digital Startups and the adoption and implementation of Lean Startup Approaches: Effectuation, Bricolage and Opportunity Creation in practice. Technological Forecasting and Social Change Volume 6 Issue 1.

Groenewegen, G and F. de Langen. (2012). Critical Success Factors of the Survival of Start-Ups with a Radical Innovation. Journal of Applied Economics and Business Research JAEBR, 2(3): 155-171

Lee-Post, Anita. 2009. E-learning Success Model: an Information System Perspective. lectronic Journal of e-Learning Volume 7 Issue 1 2009, (pp61 - 70)

Nandram, S. S., and Boemans, M. (2001). De beste ondernemer: Condities voor ondernemerssucces. Breukelen: Universiteit Nyenrode.

Pérotin, V. (2012). The Performance of Workers' Cooperatives. The Cooperative Business Movement, 1950 to the Present (Comparative Perspectives in Business History, pp. 195-221). Cambridge: Cambridge University Press.

Rauch, A. (2000). Success Factors of Small and Medium Sized Enterprises. Universiteit van Amsterdam, Amsterdam.

Ries, E. (2011). The lean startup: How today's entrepreneurs use continuous innovation to create radically successful businesses. New York: Crown Business. 
Jurnal Personalia, Financial, Operasional,

Marketing dam Sistem Informasi

Performance. Volume 27 Nomor 1 Tahun 2020, 41-50

Sulaksana,U. (2004). Managemen Perubahan. Cetakan I, Yogyakarta: Pustaka Pelajar

Tech in Asia. 2018. Accessed in https://id.techinasia.com

https://usworker.coop/what-is-a-worker-cooperative/

www.cicopa.coop 